\title{
Environmental Education in Nigeria: Issues, Challenges and Prospects
}

\author{
Victoria O. Bosah \\ Micheal Okpara University of Agriculture, \\ Umudike, Abia State, Nigeria
}

\author{
Doi:10.5901/mjss.2013.v4n16p159
}

\begin{abstract}
This paper discusses Environmental Education in Nigeria as a key to creating environmental consciousness / awareness in pupils/students from their early educational career. Insufficient educational information could lead to ignorance of some important issues pertaining to global and regional concerns. The rapid societal transition with its 'positive' and 'negative' effects is enough of a scenario for the stimulation of global re-orientation of education and reduction of apathy mostly in the developing world. This paper also reviews the schools in Nigeria (primary, secondary, colleges and universities). Research questions were developed and answered with the aim to identify some of the problems, challenges and some possible solutions that could lead to the co-ordination of any new educational policy. The paper further laid emphasis on Nigerian schools as a key to environmental adequacy and knowledge in students as future influential decision makers. This is seen as a key to empowerment and participation in decision making, with regards to solving some of the world's vital environmental issues and challenges. This trend will enhance a sustainable future development.
\end{abstract}

\section{Introduction}

It is evident that our world today is quite changing and is different from that of the agricultural and the industrial revolution. The pressure on the environment due to climate change - higher temperature, shifting seasons, more frequent and extreme weather events such as floods and droughts, the challenge for food production becomes even more daunting. The intergovernmental panel for climate change (2007) noted that some African countries could face reduction in yield of up to $50 \%$ by 2020 if they fail to adapt to the changing climate.

Some human activities as a result of search for 'quality standard of living' through science and technology have brought other problems on the environment. These problems, Stead, E. and Stead, G. called "the issue wheel". Such issues include over population, greater pollution, the death and destruction caused by toxic spills and dumps, the massive deforestation of the world's rain forests for commercial purposes, the harm caused by numerous oil spills, the destruction of wildlife habitats for human development, the release of dangerous gases (greenhouse effect) in the atmosphere such as sulfur dioxide $\left(\mathrm{SO}_{2}\right)$, nitrogen oxide $\left(\mathrm{NO}_{2}\right)$, methane $\left(\mathrm{CH}_{4}\right)$, chloroflurocarbons (CFCs), the hydroxyl radical $(\mathrm{OH})$, and carbon dioxide $\left(\mathrm{CO}_{2}\right)$.

Alberti (2010) pointed out that the interaction of humans and the natural environment may be creating a unique biochemistry of the environment. Rogers and Laffoley (2011) suggested changes in social, economic and environmental consequences.

Science has also uncovered the subtle relationship between land and water as in the case of 'teleconnections' between changing land use in one place and changing precipitation patterns at great distance away. Avissar and Werth (2005) postulate that deforestation in Amazonia and Central Africa significantly reduces rainfall in the lower U.S. Midwest during critical growing seasons, while deforestation in Southeast Asia alters rainfall patterns on the Balkan Peninsula in Europe and China.

Another threat is water quality and the expansion in coverage of public water supply. This is done without making adequate provision for facilities to treat the waste water produced by the new water supply 
infrastructure. This is leading to increased and concentrated discharge of untreated sewage from communities to waterways, wetland and coastal zones. Millennium Ecosystem Assessment (2005) point to a factor of four - to eight - fold increase in waste water loading within the next four decades over most of Africa. The FAO (2010) estimates that 85\% of marine fisheries in 2008 were either fully exploited, over exploited or depleted. In addition, the unabated land and marine based pollution of our oceans and seas has prompted changes to their chemistry, temperature and current which led to ocean acidification, biochemistry loss, widespread habitat destruction, proliferation of invasive species and simplification of ecosystems. The Millennium Ecosystem Assessment (2005) reported that over the last few decades approximately 35\% of mangroves have been lost or converted and approximately $20 \%$ of coral reefs worldwide have been destroyed and $20 \%$ degraded.

The list is endless. Our environment is inseparatable from life. There is every need for the proper management of our world. This calls for the need for environmental awareness to all and sundry in schools at all levels especially in developing countries such as Nigeria which has little or no provision for such awareness in curriculum/syllabus in areas of some related subject(s) among which is EE. This activated some elites in the developed world-organization for Economic and Cooperative Development (OECD) in April 1971 to analyze the serious need and urgency of establishing and developing new teaching programmes at school, college and university. Many developing countries are beginning to realize the role of environmental education in abating the environmental issues - the African Social and Environmental Studies Programmes (ASESP) with its seat in Nairobi, Kenya encourages and promotes the creation of environmental awareness and protection in pupils and student at the same time develops useful activities for pupils and student at the same time develops useful activities for pupils during instruction. The United Nations Environmental Programme (UNEP) in 1972. The Belgrade Chapter in 1975. The earth summit also known as the United Nations Conference on Environment and Development (UNCED), the Education, Science and Documentation Centre (ZED), UNESCO is not left out.

The desire and commitment of government to tackle environment education issues in Nigeria pointed to the need to develop a baseline survey, the Nigeria living standard survey 2003/2004 for monitoring and evaluation of the various government programmes like tree planting campaign, sustainable environmental management technique such as soil erosion control, shelter belt control, afforestation and reforestation, bioregradation programme for pollution amongst others. At 2005, access to safe drinking water, as against about $80 \%$ in urban areas (NBS, 2004). Some $29 \%$ of the total population live at risk from annual floods, over $90 \%$ of the rural population depends, on the forest for livelihood and domestic energy. Since independence in 1960, successive Nigerian government have initiated and promulgated differences policies programmes and projects for environmental education in Nigeria. However, Ugwu (2006) argues that many of these policies and programmes have failed to attain their objectives or fallen short of the ends they were set up to attain.

\subsection{An Overview}

In Nigeria, the concerted effort of the Nigerian Conservation Foundation (NCF) in 1988 motivated the fusion of an environmental education element into the citizenship education curriculum in 1990 national curriculum review conference, subsequently followed by a UNESCO sponsored National Workshop on the integration of EE elements in the National School Curriculum and the teacher programme.

Education involves the impacting of knowledge and development of skills for self-realization. Salvano Briceno \& David C. Pitt (1988), "education has always been part of the process by which people become fitted to live successfully in their world. Education is concerned with development of an individuals' ability to think, reason, and create. One of its fundamental needs is how learners of all ages learn and what they can learn. The 'how' has much to do with the teacher and the 'what' of the curriculum or syllabus as the case might be; and 'kind' of interaction among the 'how', the 'what' and of course the receiver - learner.

Environment is a broad concept. It refers to all or part of an object's or a living beings surrounding. It 
becomes everything that surrounds man hence, everything that is used by man including man himself. Thomas G. Whiston described it thus: "environment is not a residual, but an entity which incorporates attitudes, values, institution economic, science and technology and ideology. He went further to state that "environment is not an issue". It is life itself. Life is the environment and the environment is life.

\section{Statement of Problem}

The basic problem in this study is to examine the possible barrier against compulsory inculcating or implementing of functional EE in all levels of education in Nigeria. It involves the consideration of environment in its totality, its interdisciplinary nature, it emphasizes active participation in solving "environmental problems". It focuses on future and current "environmental situations" it examines all development and growth from an environmental perspective. It could also promote local, national and international cooperation among others.

The aim of this study, is to provide a critical review of those factors that could oppose the functional, holistic inculcation of EE in Nigeria education. From this study, we will gain a perspective on the specific problems facing the educational system.

Finally, this study will indicate some barriers against EE and at the same time measures to be taken against the barriers.

\section{Objective of the Study}

The objective of the study is to create a holistic environmental consciousness and awareness in pupil/student as a key to future participation in community action, decision-making and problem solving in issues of environment. Such is a step towards future sustainable development.

The study intends to consider the following:

a) What are the effects of primary school teaching of EE?

b) To what extent are the people in secondary school conscious of the environmental science policies?

c) To determine the extent the policies have impacted on the Nigerian schools.

d) To determine areas problems were encountered during implementation.

\section{Methodology}

The study will undertake an arithmetic means. The method was chosen because it is the method that suit and could interpret policies on environmental science education. The main focus is on the measures to be adopted against the barriers and hindrances of effective implementation of $E E$ in all levels of education in Nigeria. The data for this study were collected from selected universities, colleges, secondary and primary schools within Abia State is SouthEast Nigeria. Others come from relevant literature, including official publication and reports and independent websites/webpages.

The reason for the sample is to obtain authentic, impartial, valid and holistic information on what could be the barriers of co-ordinating any new educational policy in all levels of education and the possible measures to abate it.

The technique of the interview is both open-ended and structured. The interview questions took care of pupil/student, teacher, head teachers, and administrators. There is also a set of questions to teacher training college. About 600 people were reached. Data recording during the interview would include note making and tape-recording. Random sampling technique was used in drawing the sample study. A total number of about 400 questioners were ultimately processed and used.

In the final analysis, the study will help to illuminate the poor/inadequate environmental ethics, 
ignorance and awareness in schools (pupils and students). The finding of the study would be of great value in formulating policies for better management of education sector in the country and also for creating a more stable educational systems.

Table 1: Status of environmental education as a course in primary schools in Umuahia North L.G.A of Abia State Nigeria

\begin{tabular}{|l|l|c|c|}
\hline \multirow{2}{*}{ S/No } & \multicolumn{1}{|c|}{ Item } & \multicolumn{2}{c|}{$\%$ of Responses } \\
\cline { 3 - 4 } & & Yes & No \\
\hline 1. & Content of Environmental Education (EE) being satisfactory & 80.00 & 20.00 \\
\hline 2. & Encourage EE as a core subject & 60.00 & 40.00 \\
\hline 3. & EE incorporated into other subjects & 70.00 & 30.00 \\
\hline 4. & EE taught as a compulsory course in the primary school & 55.00 & 45.00 \\
\hline 5. & Desired change in attitude and behavior through the learning /teaching of EE & 65.00 & 35.00 \\
\hline 6. & Environmental management issue to be addressed & 70.00 & 30.00 \\
\hline 7. & Universal Basic Education curriculum containing EE Programme & 50.00 & 50.00 \\
\hline 8. & $\begin{array}{l}\text { Teaching/learning of EE at the early stages of education would enhance } \\
\text { environmental awareness }\end{array}$ & 70.00 & 30.00 \\
\hline 9. & Teaching/ learning of EE would help solve environment issues in future & 80.00 & 20.00 \\
\hline 10. & Occasional going on field trip or excursion & 65.00 & 35.00 \\
\hline
\end{tabular}

Table 1 Summarizes respondents answer on the status of Environmental Education (EE) as a course in Primary Schools in Umuahia North L.G.A in Abia State Nigeria. Eighty-percent (80\%) of the respondents agreed strongly that they are satisfied with content of Environmental Education EE in the school. Twenty percent $(20 \%)$ does not show satisfaction. A number of about sixty percent (60\%) of the respondents explained that EE is offered as a compulsory course in the school while forty percent $(40 \%)$ prefer it not integrated into other subjects. Seventy percentage (70\%) of the respondents stressed that EE should be taught as a core subject in the school. Thirty percent (30\%) prefer it as an integrated course. Fifty-five percent $(55 \%)$ of the respondents stated that EE should not be made compulsory, while forty-five percent(45\%) suggest it should be made compulsory.

Sixty-five percent $(65 \%)$ of the respondents suggest that desired change in attitude and behavior towards the environment can be achieved through the learning /teaching of EE while thirty-five percent (35\%) disagree with that.

Seventy percent (70\%) of the respondents stressed that Environmental management issues need to be addressed while (30\%) does not see the need. Fifty percent (50\%) of the respondent agree that the Universal Basic Education Programme stresses on EE studies while another fifty percent (50\%) disagrees with it. Seventy percent $(70 \%)$ of the respondents explained that the environment would be better managed if its taught at early stages of education. Thirty percent (30\%) of the respondent stated that EE may not need to be taught from early state.

Eighty percent (80\%) of the respondent explained the need of teaching and learning EE as a means to solve environmental issues in future while twenty percent $(20 \%)$ do not think such. Finally sixty-five percent $(65 \%)$ of the respondents stress that they often go on excursion and field trip once in awhile but thirty-five percent (35\%) explain that they do not go on excursion at all. 
Table 2: Status of teaching environmental education in secondary schools in Umuahia North L.G.A. of Abia State, Nigeria

\begin{tabular}{|l|l|c|c|}
\hline \multirow{2}{*}{ S/No } & \multicolumn{1}{|c}{ Item } & $\%$ of Responses \\
\cline { 3 - 4 } & & Yes & No \\
\hline 1. & Students offering Environmental Education as a subject in the school & 15.00 & $85 \%$ \\
\hline 2. & Environment Education to be taught as a core subject in the school & 100.00 & 0.00 \\
\hline 3. & Disposal of refuse/waste pollution around the compound satisfactory & 35.00 & 65.00 \\
\hline 4. & Persons that are comfortable with the management of other forms of waste disposal. & 40.00 & 60.00 \\
\hline 5. & Awareness programme to be created on the issue of Environmental Education (EE) & 100.00 & 0.00 \\
\hline 6. & Other subjects having topics of EE & 45.00 & 55.00 \\
\hline 7. & Availability of other literature materials and standard text book on EE & 25.00 & 75.00 \\
\hline 8. & Planting of trees since the session resumed & 30.00 & 70.00 \\
\hline 9. & Invitation of environmental management personnel to enlighten the pupil & 15.00 & 85.00 \\
\hline 10. & Workshop and seminar attended or conducted on environment issues & 35.00 & 65.00 \\
\hline
\end{tabular}

Table 2 summaries respondent answers on the status of Environmental Education (EE) as a course in secondary school in Umuahia North Local Government Area of Abia State, Nigeria. Eighty-five percent (85\%) of the respondent explained that Environmental Education is not offered as a subject or course in the school. However, $15 \%$ of the respondents stated that Environmental Education is offered in other courses in their schools.

Almost all respondent (100\%) agree that Environmental Education (EE) should be taught as a core subject. Negligibly, every respondent disagrees that EE should not be taught as a core subject. About $65 \%$ of respondent agree that refuse and waste deposits pollute the school compound while $35 \%$ (thirty-five percent) are comfortable with the management of other forms of waste disposal in the school.

About sixty percent(60\%) of the respondent stressed that there is adequate disposal of refuse/waste in the school while forty strongly believe that there could be improvement on refuse/waste disposal. Almost all respondent hundred percent agree that a better awareness programme needs to be created on Environmental Education (EE).

Fifty-five percent (55\%) of the respondent agree that most subjects they learn contain many topics found in Environmental Education while forty-five percent(45\%) stress that few of such topics are found in other core subjects.

Seventy-five percent (75\%) of the respondent disagree that literature materials and standard text books containing Environmental Education are commonly found in the school library while twenty five percent (25\%) agree that some of the books within their reach contains issues on the environment.

Vehemently, seventy (70\%) of the respondent agree that trees were planted around the school. While thirty percent $(30 \%)$ stress that trees were not planted in the compound. In the same light, eighty-five percent(85\%) of the respondent stressed that personnels of environment has not visited the school to enlighten the pupil on matters of the environment while fifteen percent (15\%) agree that they have visited.

Conclusively, sixty-five (65\%) percent of respondent requested that seminars and workshops should be regularly conducted on environmental issues while the remaining thirty-five (35\%) sees no need of such workshops. 
Table 3: Status of environmental education as a course in teachers' training college Arochukwu in Abia State, Nigeria.

\begin{tabular}{|l|l|c|c|}
\hline \multirow{2}{*}{ S/No } & \multicolumn{1}{|c|}{ Item } & $\%$ of Responses \\
\cline { 3 - 5 } & & Yes & No \\
\hline 1. & Student - Teachers offering Environmental Education as a compulsory course in the school & 25.00 & 75.00 \\
\hline 2. & School management occasionally conducting seminars on environmental management issues & 10.00 & 90.00 \\
\hline 3. & Teachers/lecturers having adequate knowledge of EE & 50.00 & 50.00 \\
\hline 4. & Need for environmental problems to be addressed & 95.00 & 5.00 \\
\hline 5. & Graduating qualified teachers to handle EE & 15.00 & 85.00 \\
\hline 6. & Teaching/learning of EE as a core subject in schools & 35.00 & 65.00 \\
\hline 7. & Need to improve on the existing syllabus/content of EE & 80.00 & 20.00 \\
\hline 8. & Provision of special financial allocation to the learning and teaching of EE & 90.00 & 10.00 \\
\hline 9. & Teaching/learning of EE to secure the environment in future & 100.00 & 0.00 \\
\hline 10. & Use of models and aids in the teaching and learning of EE & 80.00 & 20.00 \\
\hline
\end{tabular}

Table 3 summarizes respondent answers on the status of Environmental Education (EE) as a course in Teachers' Training Colleges in Abia State, Nigeria. Seventy five percent (75.00\%) of the respondents explained that Environmental Education is not offered as a compulsory course in their schools. However, $25 \%$ of the respondents stated that Environmental Education is offered as a compulsory course in their institutions/colleges.

Most (90.00\%) of the respondents stated that their school management do not conduct seminars on Environmental Education. However, $10.00 \%$ of the respondents disagree that seminars are occasionally conducted in their schools. Fifty percent (50.00\%) of the respondents agree that their teachers have adequate knowledge of the contents of Environmental Education, equally,(50\%) disagree with their teachers not having adequate knowledge of the subject matter. At most all the respondents hundred percent $(100.00 \%)$ of the respondents stressed the need for environmental problems to be addressed and on time.

Fifteen percent $(15 \%)$ of the respondent stressed that teachers of the college graduate with wellequipped knowledge of EE while eighty-five percent (85\%) graduates are not adequately equipped to tackle environment challenges.

Thirty-five percent (35.00\%) of the respondents prefer that Environmental Education should be taught as a separate course in Teaching Training Colleges. However, $65.00 \%$ of the respondents do not advocate that Environmental Education should be taught as a separate course.

Most $(80.00 \%)$ of the respondents stressed the need to improve the existing course content of Environmental Education in the Teachers' Training Colleges, while twenty percent(20\%) do not see a need for that. Almost ninety- percent (90.00\%) of the respondents suggest that the State and Federal Governments should provide financial allocation to the study of Environmental Education., while ten percent $(10 \%)$ does not see the need in place of others. All $(100.00 \%)$ the respondents believe that Environmental Education will help to secure a sustainable environment. Eighty percent (80.00\%) of the respondents advocated that the use of models in environmental education should be encouraged. 
Table 4: Status of environmental education among administrating and teachers of the university of agriculture, Umudike, Umuahia, Abia State, Nigeria

\begin{tabular}{|l|l|c|c|}
\hline \multirow{2}{*}{ S/No } & \multicolumn{1}{|c|}{ Item } & \multicolumn{2}{c|}{$\%$ of Responses } \\
\cline { 3 - 4 } & & Yes & No \\
\hline 1. & $\begin{array}{l}\text { Administrators - teachers offering Environmental Education (EE) as a compulsory course } \\
\text { in the school }\end{array}$ & 60.00 & 40.00 \\
\hline 2. & Environmental Education topics incorporated in other courses & 75.00 & 25.00 \\
\hline 3. & $\begin{array}{l}\text { School management occasionally conducting seminars and workshop on environmental } \\
\text { management issues. }\end{array}$ & 65.00 & 35.00 \\
\hline 4. & Environmental Education to be taught as a core/compulsory course in the school & 85.00 & 15.00 \\
\hline 5. & Challenges encountered in the teaching and learning of EE in its incorporated subjects & 65.00 & 35.00 \\
\hline 6. & Allocation of financial and personnel resource in the teaching/learning of EE & 85.00 & 15.00 \\
\hline 7. & Awareness of climate change as a trend globally & 85.00 & 15.00 \\
\hline 8. & Time allocated to EE with other core subjects & 35.00 & 65.00 \\
\hline 9. & Use of teaching aids and audio - visuals in the teaching/learning of EE & 100.00 & - \\
\hline 10. & Teaching and learning of EE as a core subject to help create better awareness on & 100.00 & - \\
\hline
\end{tabular}

Table 4 summarizes respondent answers on the status of Environmental Education (EE) as a course in the University of Agriculture, Umudike, Abia State, Nigeria. Sixty percent (60\%) of the respondent explained that Environmental Education is not offered as a compulsory course in their schools. Alternatively, forty percent (40\%) of the respondent stated that Environmental Education is offered as a compulsory course in their institution/colleges.

A total number of seventy-five percent (75\%) of the respondent agreed that environmental topics are incorporated in other relative courses/programmes taught in the school. However, twenty-five percent (25\%) of the respondents stated that environmental education topics are not integrated into their courses. Sixty-five percent of respondent agrees that the school management occasionally conduct seminars on environmental issues in the school. While thirty-five (35\%) stated clearly that such seminars/workshop have not being held recently.

Eighty-five percent (85\%) of the respondent express vividly that Environmental Education should be taught as a core or general course in the school while fifteen percent (15\%) stated that it could be neglected.

Sixty-five percent (65\%) of the respondent who organize and learn Environmental Education in other relative fields states clearly that they encounter challenges both in teaching and learning of the subject in other courses, while thirty-five(35\%) admit that they are comfortable with it in other field of study.

Eighty-five percent of the respondent stressed the need for financial and personnel resource allocation in the teaching and learning of Environment in the school, while fifteen percent (15\%) suggest that there may not be need.

Eighty-five percent of the respondent agree to be aware of the global trend in climate change while fifteen percent $(15 \%)$ sees it as normal and feels indifferent.

Thirty-five percent (35\%) of the respondent stressed the importance of time extension and allocation of environmental education needs to be increase to cover up the expected needs, while fifteen percent (15\%) suggest that there may be no need.

A hundred percent (100\%) the respondent agrees that modern teaching aids is needed in the teaching and learning of various topics in EE, while nobody objects to the use of audio-visual aids.

Finally, hundred percent (100\%) of the respondent also agrees strongly the teaching and learning of EE as a core in subject school curriculum would help create better awareness of the environment in the society. 


\section{Discussion of Findings}

The results and finding of the study could be said to have met the aim and purpose of the study, which includes the factors that could vitiate the functional implementation of new educational policies in educational system of Nigeria Education at all levels.

The study revealed that should be the 'institution' qualified for carrying out the policy. The use of computer by teacher should be intensified at all level since information and communication technology is reshaping the world into a small global village.

\subsection{On the part of Teacher}

Report from study showed the objectives of educational system on should show concern on problems like; inadequacy of teachers, poor conditions of service (which could breed care-free attitude and non-chalante) incompetence, lack of relevant teaching/learning aid related to poor funding, poor management and improper implementation.

On the pupil/students, in adequate knowledge of environmental issues and problems could be as a result of deficiency in school curriculum and syllabus. It could be corrected by introducing and co-ordinating new educational policies such as EE in the school curriculum and syllabus which would expose the pupil to environmental issues and empower/equip them to face world environmental challenges at local, regional national and international levels.

\subsection{Funding of the System}

Education being instrument of change demands proper finding. Adequate funding at the Federal, State and Local Government could cater for teaching/learning of materials to enhance EE. The poor funding of education tells on both teachers, the school and pupil. Poor services, large number of pupil, deliabilated buildings, insufficient materials due to poor funding retards the system.

Regular payment of salary and other rewards and remuneration of various kinds, proper equipment of schools at all levels (current laboratory equipment, machines, conductive environment well-constructed classroom and other basic amenities is better formed would help in achieving the teaching and learning of EE.

\subsection{Change in Curriculum}

Co-ordination of EE in the school syllabus and its realization depends on educational planners and government. Realization of EE objectives of included in the curriculum demands experts to impact the knowledge training/retaining of teachers towards the new programmes.

Specially designed programmes for teachers/would be teachers in relation to duration, content, mode of practice would enhance the objectives of a new educational policy. The new policy requires new knowledge, experts in the new policy, willingness and commitment from government to meet its goals and objectives.

\subsection{Change in attitude}

The attitude of people into different levels might help in the learning/teaching of EE. The teacher, pupil, administrative ordinary people on the street by living a discipline, dedicative selfless, honest and care of our environment might be a key to achieving the objectives of the new educational policy.

Finally, there should be mass support of EE in school syllabus at any educational 'level' whatsoever as 
means of meeting the demands and challenges of the new 'jet era' caused by everyday advancement in science and technology which affects the environment intensively. Environmental education is essential for developing a healthy, sustainable society. Many current environmental problems are due to ignorance of basic ecological facts of life. To counteract this problem, well funded, scientifically accurate and carefully designed educational courses in schools and colleges are needed for an overall awareness of the public through learning basic natural resources so as to ensure that on-coming generation will understand the value and importance of pollution control, resource conservation and wildlife habitat protection etc.

Environmental education is essential for developing a healthy, sustainable society. Many current environmental problems are due to ignorance of basic ecological facts of life. To counteract this problem, well funded, scientifically accurate and carefully designed educational courses in schools and colleges are needed for an overall awareness of the public through learning basic natural resources so as to ensure that on-coming generation will understand the value and importance of pollution control, resource conservation and wildlife habitat protection etc.

\section{References}

Adara, O.A. (1997) Improving the quality and outreach of EE in Nigeria; World council for curriculum and instruction.region.Jos.Publishers.P.32.

Adeboye .O, A (2002) Vision Mission of preprimary and primary education in Nigeria. In vision and mission of education in Nigeria

Alex. Hyellaiya. Journal of resources Vol.2 1 July 2012

Briceno, S. \& Pitt, D.C (1998) New ideas in environmental education.P.34

Enema F.O(2004) Vision and Mission of teacher and Education. Nigerian journal of Academic excellence

Fontana, D. (1984) Behaviourism and learning theory in education. Scottish academic press; Edinbungh, P.108

Kola-Olusanya .A(1998);concept mapping and analogies in environmental education in Nigeria

Madunewesi J.E( 2003) Emergent curriculum issues. How are the teacher empowering Abuja NERDC

Mgbodile T.O(1986)Educational Administration and supervision. University of Nigeria. Institute of Education and Heinemann Educational Book

Ocho .L.O. (2005)Issues and consenses in Education and life. Enugu: Institute of Development Studies.

Okoye J.D. (2004) Poor educational foundation in Nigeria Newswatch Magazine July 192005 pg. 8

Renner, Stafford, Lawson, Mckinnon, Friot \& Kellog (1976) Research, teaching and learning with the Piaget model: University of Oklahama press.

Stead, W.E. \& Stead, J.G (1996).Management for a small planet. Sage publication: London, New Delhi

Whiston, T.G(2000) Environmental consciousness and the challenges and barrier to communication environmental indicators. Austrian research centers P.I 
